\title{
The Potential of Wheat Straw Fibre in Treatment of Heavy Metal-Contaminated Soil: Mechanical Properties Research
}

\author{
Tian Angran', Chen $\mathrm{Ji}^{2 *}$, Feng Zheyuan ${ }^{1}, \mathrm{Xu} \mathrm{Qi}^{1}$, Luo Xinyu${ }^{1}$, Tang Qiang ${ }^{1,2 * *}$ \\ ${ }^{1}$ Soochow University, No.8, Jixue Road, Xiangcheng District, Suzhou, 215131, China \\ ${ }^{2}$ Graduate School of Global Environmental Studies, Kyoto University, Sakyo-ku, Kyoto, 606-8501, Japan
}

Received: 23 June 2021

Accepted: 15 November 2021

\begin{abstract}
Soil contamination by heavy metals threatens human health, and the disposal of heavy metal- contaminated soil remains a serve problem worldwide. The heavy metals in soil degrade soil mechanical properties, while the utilization of contaminated soil is difficult. In previous studies, to decrease the impact of heavy metals, different types of cement and fibres were used to improve soil mechanical properties. This paper investigates the validity of combined use of wheat straw fibre and Portland cement in heavy metal-contaminated soil, and discusses the effect in mechanical properties. Wheat straw reinforced soil (WS), wheat straw and cement reinforced soil (WCS) and wheat straw and cement reinforced heavy metal-contaminated soil (WCCS), were tested via different heavy metal content and type, different fibre content and length, different cement content and curing age. The unconfined compressive strength (UCS), failure strain, deformation modulus, cohesion and internal friction angle were determined by series of unconfined compressive strength tests and direct shear tests.
\end{abstract}

Keywords: heavy metal, treatment of contaminated soil, wheat straw fibre, mechanical properties

\section{Introduction}

With the acceleration of industrialization and urbanization, more toxic and harmful chemicals are discharged into the soil, which contaminate the soil seriously [1-3]. Soil is one of the most important natural resources, which is often used as subgrade material in road construction [4-5]. Owing to the characteristics of wide sources, high toxicity, and long latency, heavy metals not only degrade the mechanical properties

*e-mail: chenji.jason7s@gmail.com

**e-mail: tangqiang@suda.edu.cn of soils, but also expose a great harm to human health [6-8]. Therefore, the improvement of contaminated soil properties has been a concern worldwide. According to some previous studies, the method of solidification/ stabilization has been proved effective and practical [9-10]. This method decreases the solubility, migration, leaching toxicity and bioavailability of heavy metals by using a binder to change the ion form of heavy metals. The reactions between the binder and heavy metals include adsorption precipitation, co-precipitation and ion exchange. Portland cement is one of the common methods in the solidification/stabilization remediation, and the unconfined compressive strength test (UCST) is often conducted to evaluate soil properties [11]. 
It is considered that the presence of heavy metal decreases the unconfined compressive strength (UCS) of soils, while different concentration and type of ions have different effects [12]. From some studies referring to the strength of cement-solidified soil contaminated by $\mathrm{Pb}^{2+}$, the strength of heavy metal-contaminated soil is greatly improved by cement [13-14].

As known to all, pavement structure is a bearing structure, which possesses a capacity of certain intensity and anti-deformation [15-17]. Numerous studies have illustrated that fibres can improve both intensity and anti-deformation of soil [18-21]. Natural fibre and synthetic fibre are the two divided types according to sources source. In some previous studies, polypropylene fibres were chosen as reinforcement to evaluate the strength and deformation of reinforced soil. It is indicated that the addition of fibre can improve compression, shear and deformation properties of soil. When the fibre content is $0.2 \%$, with $2.5 \mathrm{~cm}$ of length, the reinforcement reaches the maximum effect [19]. Some other studies carried out direct shear tests on the fibre and cement reinforced soil, and discovered that the improvement effect of fibre on strength of cementsoil was more significant [20]. It was noted that with the addition of wheat straw, the cohesion of the soil increased, so did the capacity of anti-deformation [21].

Wheat straw is the residue of wheat harvest, which occupies a large quantity around the world [22-24]. Over 7 million tons of straw are produced in China every year. Although there are many methods for straw treatment, such as crushing returning and biomass power generation, the proportion of treatment is still less than $30 \%$ [25]. Therefore, a large number of wheat straw are abandoned, resulting in serious air pollution and ecological problems [26-27]. Such problems can be solved if straw can be recycled as reinforcement in heavy metal-contaminated soil remediation. In this paper, wheat straw was chosen as reinforcement and cement was used as solidified material. UCST and DST were conducted to evaluate the properties of wheat straw reinforced soil (WS), wheat straw and cement reinforced soil (WCS) and wheat straw and cement reinforced heavy metal-contaminated soil (WCCS). The influence of fibre content, fibre length, cement content, curing age, heavy metal content and type were discussed via UCS, failure strain, deformation modulus, cohesion, internal friction angle. This paper is to investigate the validity of mechanical properties within WCCS.

\section{Materials and Methods}

\section{Materials}

Soil

In this paper, the soil is a mixture of commercial kaolin and sand at the ratio of 3:7. The properties of kaolin and sand are summarized in Table. 1. The soil was dried for 24 hours at temperature of $105^{\circ} \mathrm{C}$ and sifted through $1 \mathrm{~mm}$ sieve before tests. in According to the compaction test (JTG E40-2007), the optimum water content of the soil is $12 \%$, while the maximum dry density is $1.98 \mathrm{~g} / \mathrm{cm}^{3}$. The tests were conducted at the optimum water content, with actual dry density (almost $95 \%$ of the maximum dry density).

\section{Cement}

The cement used in the tests is an ordinary Portland cement. The cement is mainly composed of $\mathrm{CaO}, \mathrm{SiO}_{2}$, $\mathrm{AlO}_{3}, \mathrm{Fe}_{2} \mathrm{O}_{3}, \mathrm{SO}_{2}, \mathrm{MgO}, \mathrm{K}_{2} \mathrm{O}$ and $\mathrm{Na}_{2} \mathrm{O}$. The indexes of Portland cement are shown in Table. 2. Aiming to mix sufficiently, the cement was also dried and sifted through $3 \mathrm{~mm}$ sieve.

Table. 1. Properties of soil.

\begin{tabular}{|c|c|c|c|c|}
\hline Property & Standard & Unit & Kaolin & Sand \\
\hline Moisture & JIS A 1203 & $\%$ & 2.90 & 0.39 \\
\hline $\mathrm{pH}$ & JGS 0211 & & 4.70 & 7.50 \\
\hline $\mathrm{EC}$ & JGS 0212 & $\mathrm{mS} / \mathrm{cm}$ & 0.42 & 0.06 \\
\hline \multicolumn{5}{|c|}{ Grain size distribution } \\
\hline Clay $(\leq 0.005 \mathrm{~mm})$ & \multirow{3}{*}{ GB/T50123-1999 } & $\%$ & 56.40 & 0.10 \\
\hline Silt $(0.005-0.075 \mathrm{~mm})$ & & $\%$ & 18.80 & 2.98 \\
\hline Sand $(0.075-2 \mathrm{~mm})$ & & $\%$ & 24.80 & 96.92 \\
\hline \multicolumn{5}{|c|}{$\mathrm{N}_{2}-\mathrm{BET}$} \\
\hline Correlation coefficient $\left(\mathrm{R}^{2}\right)$ & & & 0.99 & \\
\hline Specific surface area & & $\mathrm{m}^{2} / \mathrm{g}$ & 29.41 & \\
\hline Diameter & & $\mathrm{nm}$ & 29.97 & \\
\hline Pore volume & & $\mathrm{cm}^{3} / \mathrm{g}$ & 0.22 & \\
\hline
\end{tabular}


Table. 2. Properties of Cement.

\begin{tabular}{|c|c|c|c|c|}
\hline Property & Standard & Unit & Value & Value of Standard \\
\hline Initial setting time & GB/T 1346-2011 & $\mathrm{h}$ & 5.6 & $>3$ \\
\hline Final setting time & GB/T 1346-2011 & $\mathrm{h}$ & 7.8 & $>6,<10$ \\
\hline Stability & GB/T 1346-2011 & - & Satisfied & up to standard \\
\hline Cement fineness & GB/T 1345-2005 & $\%$ & 4.3 & $\leq 10 \%$ \\
\hline Bending strength & \multirow{3}{*}{ GB17671-1999 } & & & \\
\hline 3 days & & $\mathrm{MPa}$ & 3.3 & $\geq 2.5$ \\
\hline 28 days & & $\mathrm{MPa}$ & 6.4 & $\geq 5.5$ \\
\hline \multicolumn{5}{|c|}{ Compressive strength } \\
\hline 3 days & \multirow{2}{*}{ GB17671-1999 } & $\mathrm{MPa}$ & 14.7 & $\geq 10.0$ \\
\hline 28 days & & $\mathrm{MPa}$ & 39.6 & $\geq 32.5$ \\
\hline
\end{tabular}

\section{Wheat Straw Fibres}

Natural wheat straw fibres used in the tests is from Suqian, Jiangsu, China. The physical-mechanical parameters are summarized in Table. 3. The wheat straw was cleaned to remove impurities, then selected and cut into a certain length. The length of wheat straw selected for the test ranges from $5 \mathrm{~mm}$ to $10 \mathrm{~mm}$ and $10 \mathrm{~mm}$ to $20 \mathrm{~mm}$. The fibre content, which is the mass ratio with soil, fixes at the value of $0.05 \%, 0.1 \%, 0.2 \%$ and $0.4 \%$.

\section{Heavy Metal}

The chemicals used in the tests include $\mathrm{PbCl}_{2}$, $\mathrm{CuCl}_{2} \cdot 2 \mathrm{H}_{2} \mathrm{O}$ and $\mathrm{ZnCl}_{2}$, while the concentrations of heavy metals are $1000 \mathrm{mg} / \mathrm{kg}, 5000 \mathrm{mg} / \mathrm{kg}$ and 10000 $\mathrm{mg} / \mathrm{kg}$. The mass of heavy metals in the soil is $0.1 \%$, $0.5 \%$ and $1 \%$ of dry soil, respectively. For convenience of marking, soil with different metal concentration (taking $\mathrm{Pb}$ as an example) are marked with $\mathrm{Pb} \mathrm{0.1,} \mathrm{Pb}$ 0.5 and $\mathrm{Pb} 1$.

\section{Specimen Preparations}

The mixture ratio of three kinds of soil is shown in Table 4, 5 and 6, including wheat straw reinforced

Table. 3. Physical-mechanical parameters of wheat straw.

\begin{tabular}{|c|c|c|}
\hline Parameter & Unit & Wheat Straw \\
\hline Shape & & Cylindrical \\
\hline Diameter & $\mathrm{mm}$ & $3-4$ \\
\hline Dispersivity & & Well \\
\hline Ultimate elongation & $\%$ & $1.13-2.30$ \\
\hline Average ultimate force & $\mathrm{N}$ & $53-104.9$ \\
\hline Thickness & $\mathrm{mm}$ & $0.498-0.665$ \\
\hline
\end{tabular}

soil (WS), wheat straw and cement reinforced soil (WCS) and wheat straw and cement reinforced heavy metal-contaminated soil (WCCS). There are three types of WCCS, which contains wheat straw and cement reinforced $\mathrm{Pb}$-contaminated soil (WCCS-Pb), wheat straw and cement reinforced $\mathrm{Cu}$-contaminated soil (WCCS-Cu) and wheat straw and cement reinforced Zn-contaminated soil (WCCS-Zn). In order to be more clearly, soil with fibre length of X mm were marked with WSX (e.g., WS5-10, WS10-20), soil with fibre content of Y\% were marked with WSY (e.g., WS0.2), while soil with cement content of Z\% were marked with CZ (e.g., C5, C7.5, C10).

The specimen preparation of UCST and DST is the same. In the UCST, three parallel specimens were shaped while there are four parallel specimens with different size in DST. The kaolin, sifted sand and cement were dried at $105^{\circ} \mathrm{C}$ for over 24 hours, then cool to room temperature. To obtain the heavy metal solution, definite dose of chloride and quantitative deionized water were mixed. Then, the kaolin, sand, cement and wheat straw fibres were mixed sufficiently to achieve ample dispersion of wheat straw fibres. At the final step, the mixtures were compacted layer by layer according to $95 \%$ of the maximum dry density and sealed into a fresh-keeping film for curing with constant temperature and humidity $\left(20 \pm 2^{\circ} \mathrm{C}\right.$ temperature; $\geq 95 \%$ humidity).

\section{Unconfined Compressive Strength Test}

The UCST and the DST were conducted referring to the Highway Geotechnical Test Rules (JTG E40-2007). The testing device of UCST was YSH-2 compactor produced by Nanjing Soil Instrument Factory. The loading step of the test was $1 \mathrm{~mm} / \mathrm{min}$, and the UCS, failure strain and deformation modulus of specimens under different conditions were measured during the test. In this test, secant modulus $\left(E_{50}\right)$ was used to represent the deformation modulus. 
Table. 4. Mixture ratio of wheat straw reinforced soil (WS).

\begin{tabular}{|c|c|c|}
\hline Fibre length/mm & Fibre content $/ \%$ & The value of $\mathrm{X}$ \\
\hline $\mathrm{X}$ & 0.2 & $5-10,10-20$ \\
\hline $5-10$ & $\mathrm{X}$ & $0,0.05,0.1,0.2,0.4$ \\
\hline
\end{tabular}

Table. 5. Mixture ratio of wheat straw and cement reinforced soil (WCS).

\begin{tabular}{|c|c|c|c|c|}
\hline Fibre length/ mm & Fibre content $/ \%$ & Cement content/ $\%$ & Curing age/ & The value of $\mathrm{Y}$ \\
\hline $\mathrm{Y}$ & 0.2 & 7.5 & 28 & $5-10,10-20$ \\
\hline $5-10$ & $\mathrm{Y}$ & 7.5 & 28 & $0,0.05,0.1,0.2,0.4$ \\
\hline $5-10$ & 0.2 & $\mathrm{Y}$ & 28 & $5,7.5,10$ \\
\hline $5-10$ & 0.2 & 7.5 & $\mathrm{Y}$ & $7,28,90$ \\
\hline
\end{tabular}

Table. 6. Mixture ratio of wheat straw and cement reinforced heavy metal-contaminated soil (WCCS).

\begin{tabular}{|c|c|c|c|c|c|c|}
\hline $\begin{array}{c}\text { Fibre } \\
\text { length/mm }\end{array}$ & $\begin{array}{c}\text { Fibre } \\
\text { content/\% }\end{array}$ & $\begin{array}{c}\text { Cement } \\
\text { content/\% }\end{array}$ & $\begin{array}{c}\text { Curing } \\
\text { age/d }\end{array}$ & $\begin{array}{c}\text { Concentration of heavy metals } \\
/ \%\end{array}$ & $\begin{array}{c}\text { Heavy } \\
\text { metal }\end{array}$ & The value of $Z$ \\
\hline $\mathrm{Z}$ & 0.2 & 7.5 & 28 & 0.5 & $\mathrm{~Pb}$ & $5-10,10-20$ \\
\hline $5-10$ & $\mathrm{Z}$ & 7.5 & 28 & 0.5 & $\mathrm{~Pb}$ & $0,0.05,0.1,0.2,0.4$ \\
\hline $5-10$ & 0.2 & $\mathrm{Z}$ & 28 & 0.5 & $\mathrm{~Pb}$ & $5,7.5,10$ \\
\hline $5-10$ & 0.2 & 7.5 & $\mathrm{Z}$ & 0.5 & $\mathrm{~Pb}$ & $7,28,90$ \\
\hline $5-10$ & 0.2 & 7.5 & 28 & $\mathrm{Z}$ & $\mathrm{Pb}$ & $0.1,0.5,1$ \\
\hline $5-10$ & 0.2 & 7.5 & 28 & 0.5 & $\mathrm{Z}$ & $\mathrm{Pb}, \mathrm{Cu}, \mathrm{Zn}$ \\
\hline
\end{tabular}

\section{Direct Shear Test}

The device used in DST was ZJ strain-controlled direct shear apparatus. In this test, quick shear test was adopted and four vertical pressures $(100 \mathrm{kPa}, 200 \mathrm{kPa}$, $300 \mathrm{kPa}$ and $400 \mathrm{kPa}$ ) were used. Moreover, the shear step of the test was $2.4 \mathrm{~mm} / \mathrm{min}$. The shear strength results of cohesion and internal friction angle under different conditions were measured respectively.

\section{Results and Discussion}

\section{Unconfined Compressive Strength Test Results}

\section{Effects of Fibre Content and Fibre Length}

Fig. 1a) shows the effect of fibre content on the UCS of WS, WCS and WCCS-Pb. It can be noted that with the increase of fibre content, the UCS of WS changes a little. Meanwhile, the UCS of WCS and WCCS-Pb varies obviously. Besides, the UCS of soil reinforced with different fibre content is less than that of unreinforced soil, which may be caused by the nonuniformity between wheat straw and soil particles. For WCS and WCCS-Pb, the existing form of wheat straw may influence the properties of soil, as a result, the UCS increases first and decreases with the increase of fibre content. Especially in relatively high fibre content, fibres were prone to agglomerate, leading to the destruction of soil. The maximum UCS of WCS corresponds to the fibre content of $0.2 \%$, while the maximum UCS of WCCS-Pb corresponds to the fibre content of $0.1 \%$, which may be related to the volume of samples and the dispersion of fibres.

The failure strain of WS, WCS and WCCS-Pb with various fibre content are shown in Fig. 1b). With the increase of fibre content, the failure strain of WCS and WCCS-Pb changes slightly and the value is less than that of WS with the same fibre content. It can be noted that the brittleness of soil increases with the adding of cement. The failure strain of WS increases in wave with the increase of fibre content, which indicated that the more fibres bring about the greater the strength, so does the deformability of soil. Fig. 1c) depicts the change of deformation modulus coincides with that of the UCS when the fibre content changes.

The influence of fibre length on the UCS, failure strain and deformation modulus are shown in Fig. 1d), e) and f) respectively. It is obvious that the fibre length represents little influence on the indexes, which may be caused by many facts. On the one hand, the wheat straw fibres with the length of 5-10 $\mathrm{mm}$ and $10-20 \mathrm{~mm}$ were 
a)

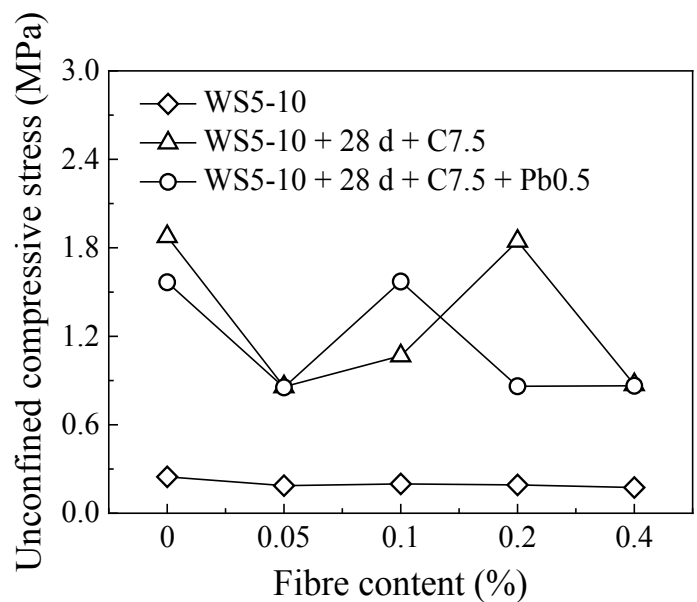

c)

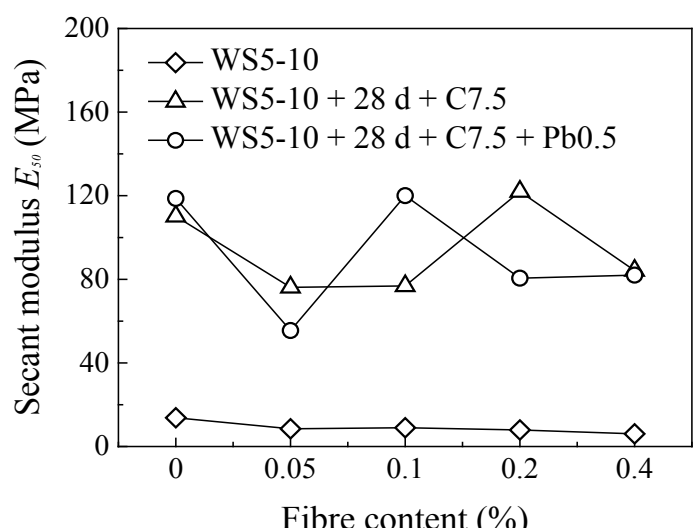

e)

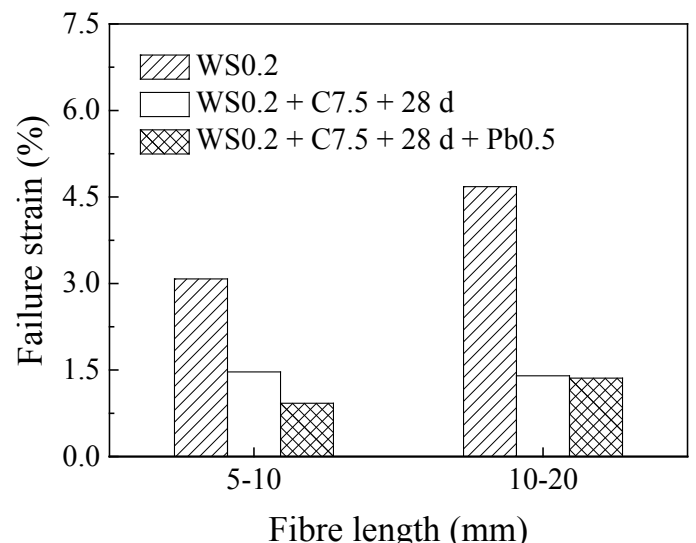

b)

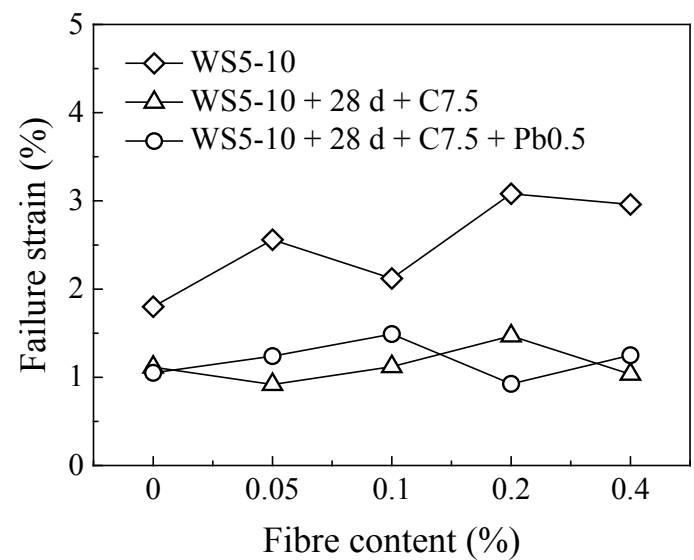

d)

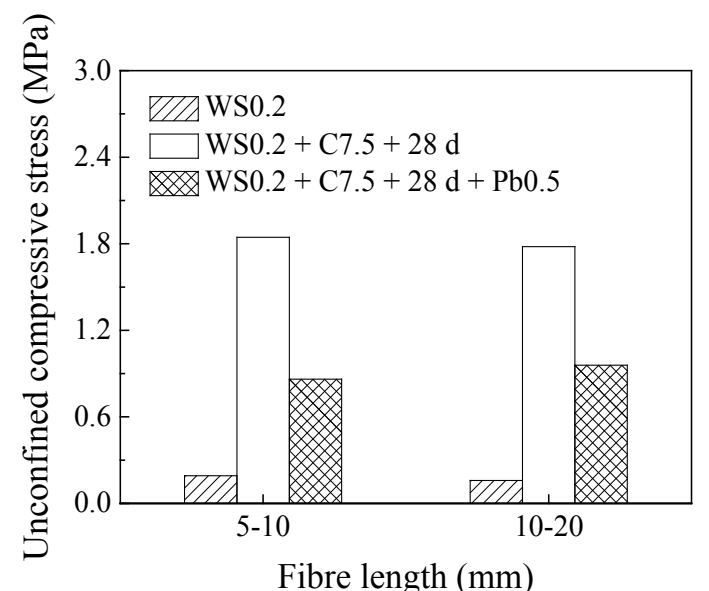

f)

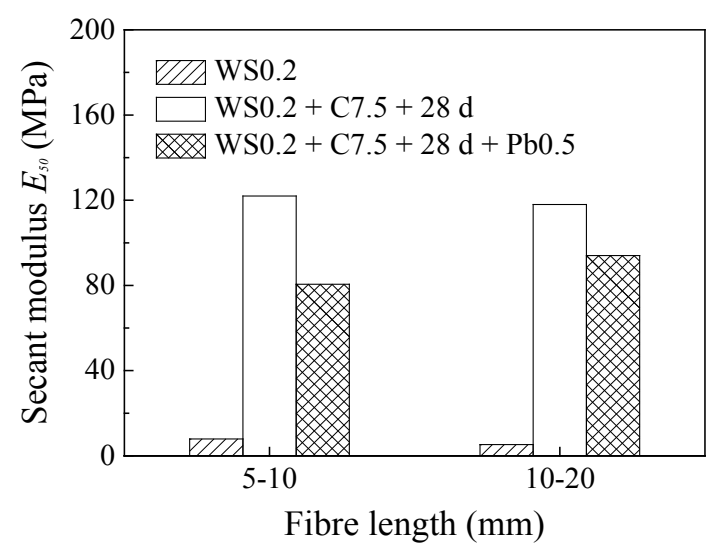

Fig. 1. Effects of fibre content and fibre length in unconfined compressive strength test.

mixed in the soil with a uniform length. On the other hand, the friction between wheat straw fibre of different length and soil particles was little different from that between soil particles. As a result, the soil UCS, failure strain and deformation modulus change little with the variety of fibre length.

\section{Effects of Cement Content and Curing Time}

Fig. 2a) presents the influence of cement content on the UCS, which shows that as the cement content increases, the UCS of WCS and WCCS-Pb increases steadily. It can be seen that the UCS difference between WCS and WCCS-Pb is little when the cement content is $5 \%$. It can be calculated that the UCS of WCS is about 1.35 times of that of WCCS-Pb. When the cement content increases to $7.5 \%$ and $10 \%$, the difference between two soils are changed to 2.17 times and 1.72 times, respectively. This indicates that when the cement content reached $7.5 \%$, the heavy metals in the soil inhibit the formation of cement-hydrate to some extent, as a result, the UCS difference between WCS and WCCS-Pb increases. When the cement content increases (reaching $10 \%$ ), more cement participate in the hydration reaction and more cement-hydrate is generated. Meanwhile, the inhibition of heavy metals on cement hydration is limited, thus the UCS difference between WCS and WCCS-Pb decreases. 
The effect of cement content on the failure strain and the deformation modulus are depicted in Fig. 2b) and c), respectively. The failure strain and the deformation modulus increase with the increase of cement content. Whatever the cement content is, the failure strain of WS is larger than that of WCCS-Pb. Besides, when in the same cement content, the overtime increase in failure strain of WCS is $41 \%$. Moreover, it can be concluded that the deformation modulus of WCS increases rapidly first and then slowly down, while that of WCCS-Pb increases slowly first and then rapidly.

Fig. 2d) presents that the curing time of cement had a significant impact on the strength. It depicts that, when the curing time is $7 \mathrm{~d}$, the UCS of WCS is 0.633

a)

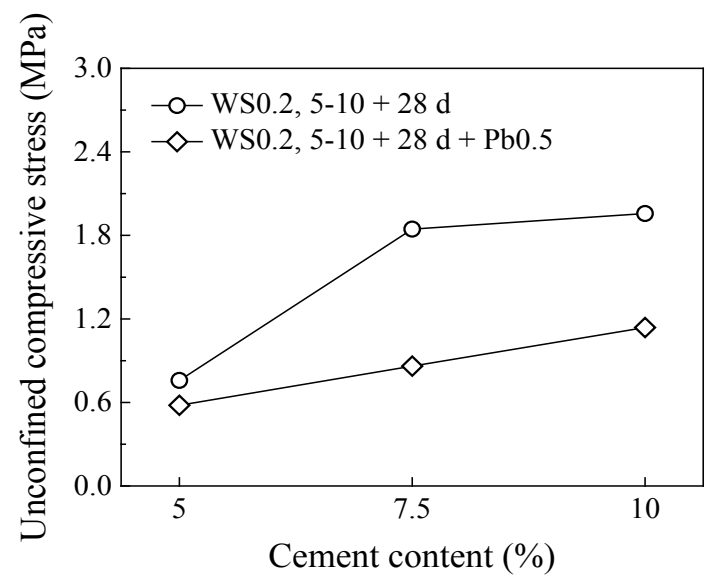

c)

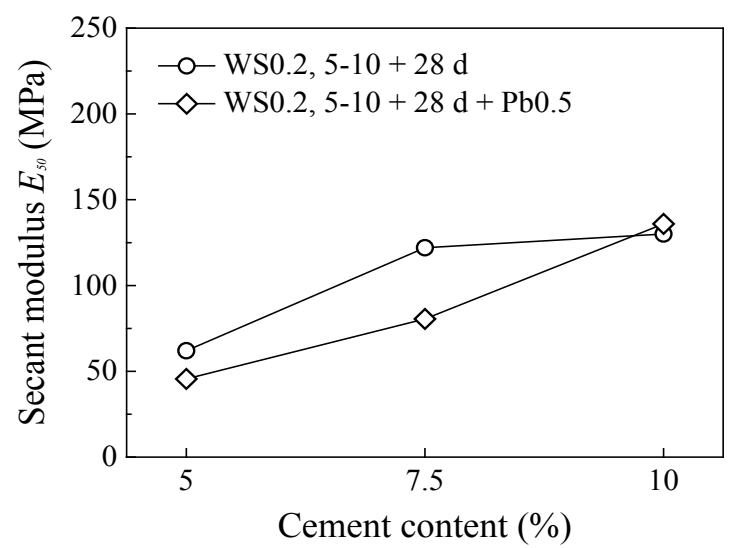

e)

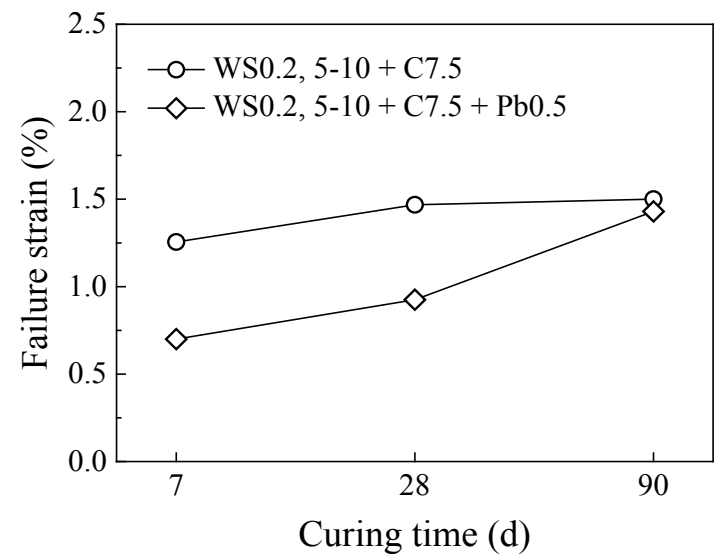

MPa. When the curing time reaches $28 \mathrm{~d}$ and $90 \mathrm{~d}$, the UCS rises to $1.845 \mathrm{MPa}$ and $1.9 \mathrm{MPa}$, which increases by $191.5 \%$ and $200.2 \%$ respectively. Besides, the UCS of WCCS-Pb with $7 \mathrm{~d}, 28 \mathrm{~d}$ and $90 \mathrm{~d}$ curing time were $0.418 \mathrm{MPa}, 0.418 \mathrm{MPa}$ and $2.009 \mathrm{MPa}$. When comparing the UCS of WCS and WCCS$\mathrm{Pb}$, it was found that the UCS of WCCS-Pb is less than that of WCS when in a shorter curing time (e.g., 7 d). However, as the curing time increases (e.g., from $28 \mathrm{~d}$ to $90 \mathrm{~d}$ ), the difference diminishes. This is because the longer the curing time is, the more sufficient the cement hydration reaction exists and the more cement-hydrates are generated to adsorb and encapsulate heavy metals to reduce the destruction. b)

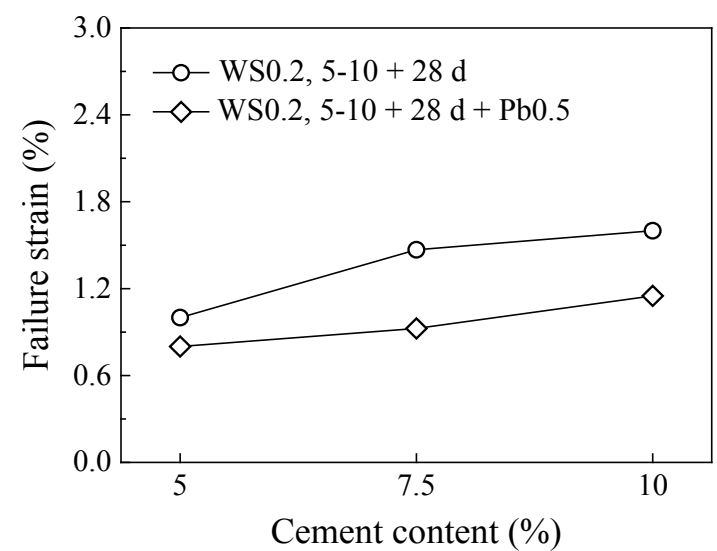

d)

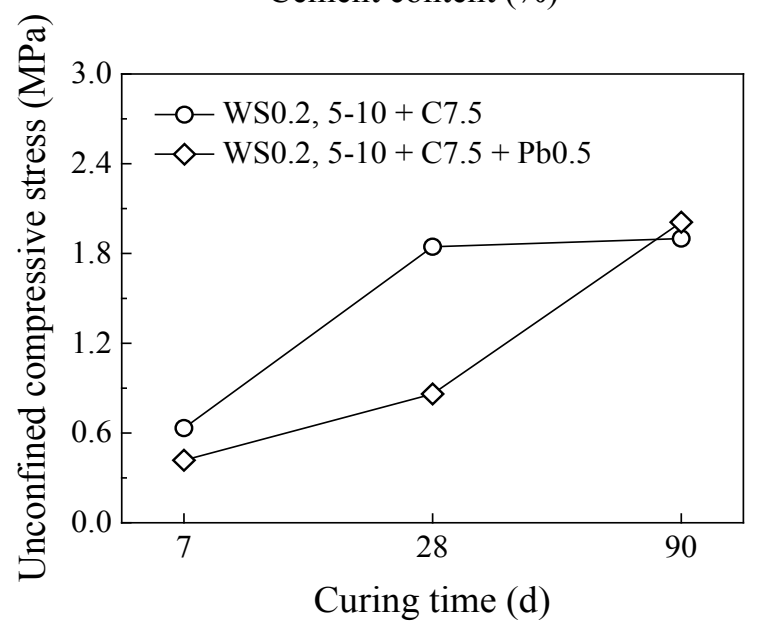

f)

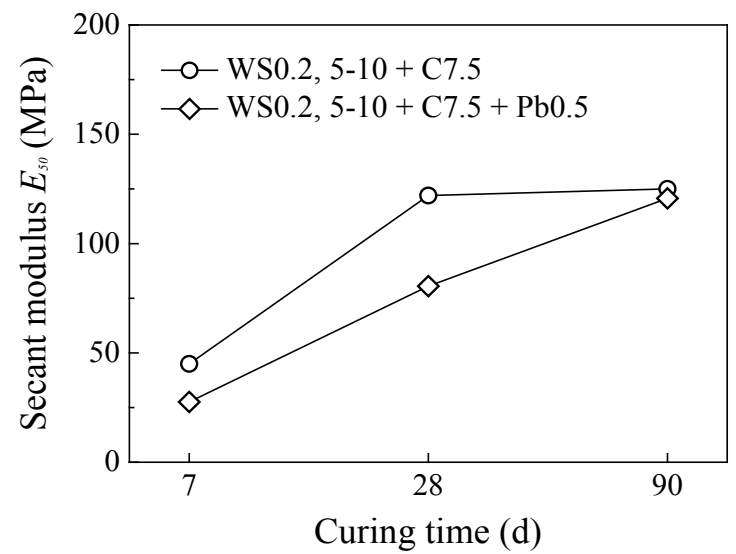

Fig. 2. Effects of cement content and curing time in unconfined compressive strength test. 
Fig. 2e) and f) depicts the failure strain and the deformation modulus of WCS and WCCS-Pb with different curing time. The trend of the failure strain and the deformation modulus were similar to that of the UCS. As the curing time increases, the failure strain and the deformation modulus of the soils increases. Moreover, the difference of the failure strain and the deformation modulus between the two soils decreases with a relatively longer curing time (e.g., from $28 \mathrm{~d}$ to $90 \mathrm{~d}$ ).

a)

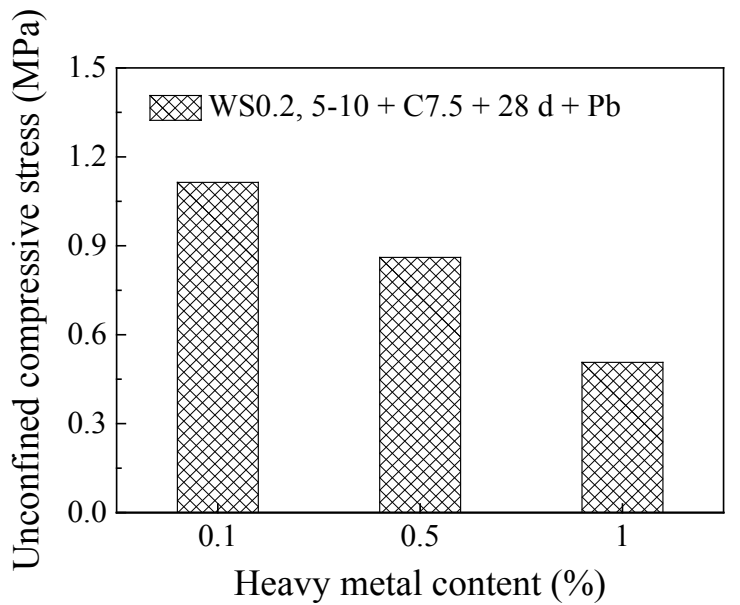

c)

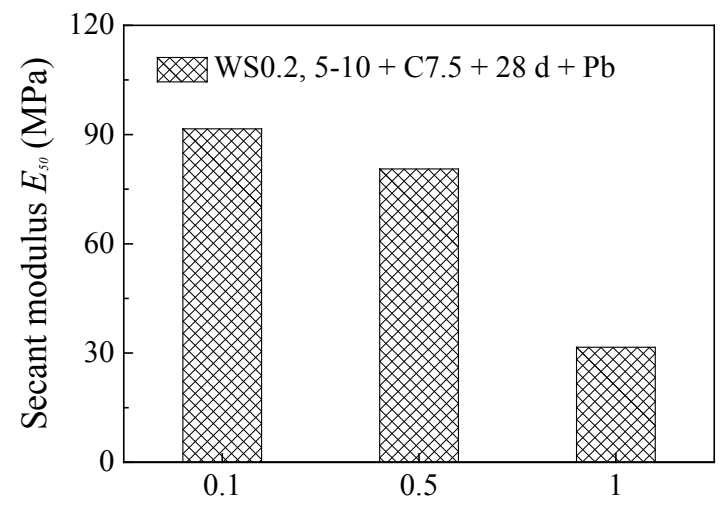

Heavy metal concentration (\%)

e)

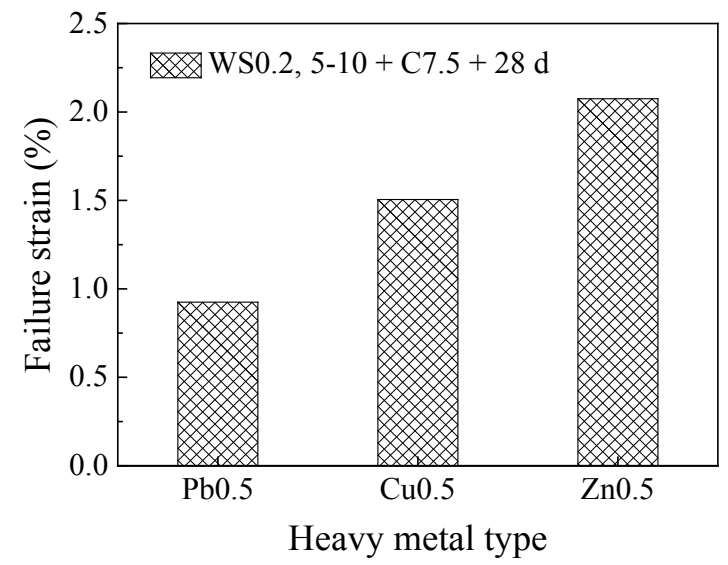

\section{Effects of Heavy Metal Content and Type}

Fig. 3a), b) and c) shows the effect of heavy metal content on the UCS, failure strain and the deformation modulus of WCCS-Pb. It can be seen that the presence of $\mathrm{Pb}^{2+}$ had a negative influence on soil strength. As shown in Fig. 3a), the UCS of WCCS-Pb decreases gradually with the increase of $\mathrm{Pb}^{2+}$ concentration. It can be calculated that as $\mathrm{Pb}^{2+}$ concentration increases from $0.1 \%$ to $0.5 \%$ and $1 \%$, the UCS decreases by $22.7 \%$ and $54.5 \%$, respectively. In Fig. 3b) and c), the failure strain of WCCS-Pb is the largest with

b)

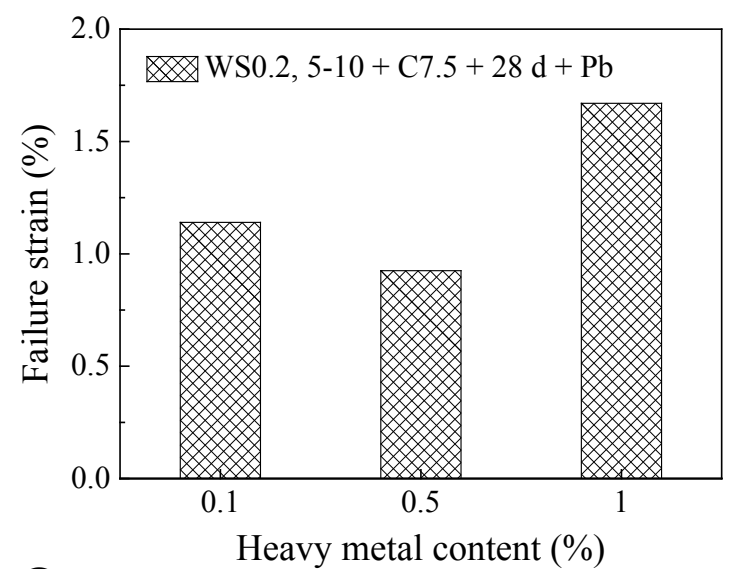

d)

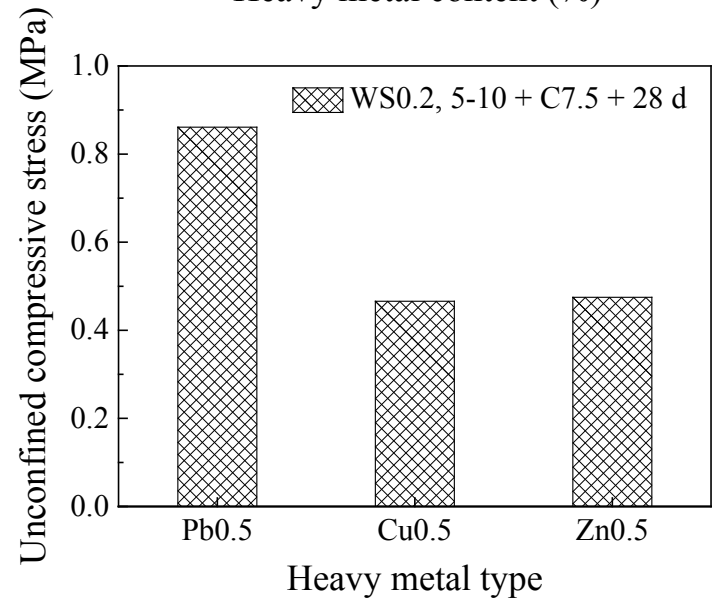

f)

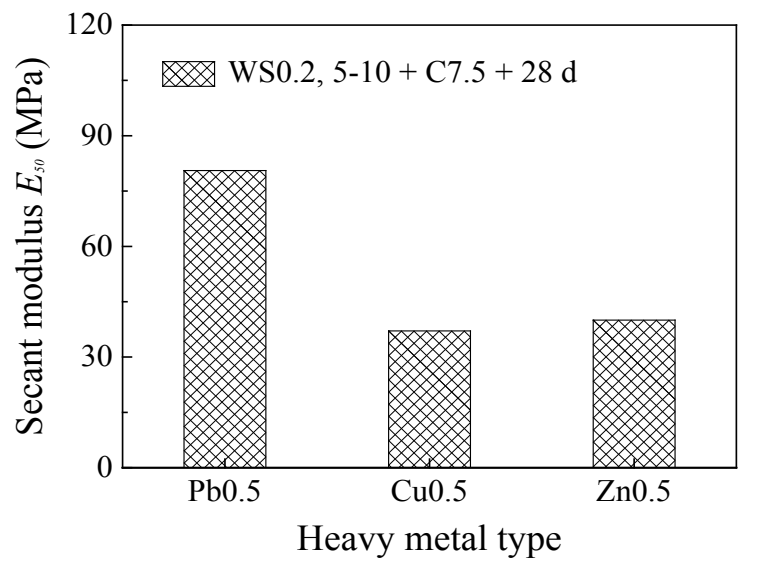

Fig. 3. Effects of heavy metal content and type in unconfined compressive strength test. 
the highest concentration of heavy metal (1\%), while the deformation modulus reaches minimum. Besides, as the heavy metal content increases, the deformation modulus of WCCS-Pb decreases, which is consistent with the change trend of the UCS [28-30].

Different heavy metal ions have different effects on WCCS. In Fig. 3d), e) and f), when the heavy metal content is $0.5 \%(5000 \mathrm{mg} / \mathrm{kg})$, the UCS of WCCS-Pb is significantly higher than that of WCCS-Cu and WCCSZn. According to some studies, solubility was an important factor, which affects the remediation effect of heavy metal-contaminated soils with the method of solidification/stabilization [31-34]. As shown in Fig. 3d) and $\mathrm{f}$ ), the UCS and the deformation modulus of WCCS-Zn are more than that of WCCS-Cu. It is considered that when in a higher heavy metal content $(5000 \mathrm{mg} / \mathrm{kg})$, the solidification effect of cement on $\mathrm{Zn}^{2+}$ is greater [35-37]. The failure strain of WCCS$\mathrm{Zn}$ is the largest, followed by WCCS-Cu and WCCS-Pb.

\section{Direct Shear Test Results}

\section{Effects of Fibre Content and Fibre Length}

Fig. 4a) and b) depicts the effect of fibre content on the shear strength indexes, including cohesion and internal friction angle. It can be seen that, with the same fibre content, the cohesion and the internal friction angle of WCS is the largest. Besides, the cohesion difference between three soils is obvious, while the internal friction angle difference is relatively little. For instance, when the fibre content is $0.2 \%$, the cohesion of WCS and WCCS-Pb with the fibre length of $5-10 \mathrm{~mm}$ are 3.76 times and 2.47 times of WS. Nevertheless, the internal friction angle difference between them are only 1.26 times and 1.07 times of WS.

The influence of fibre length on shear strength indexes are presented in Fig. 4c) and d). As the fibre length increases, soil cohesion and internal friction angle exists almost no change, which may be caused by no significant length difference in the fibres mixed in the final soil samples.

\section{Effects of Cement Content and Curing Time}

In Fig. 5a), the cohesion of WCCS-Pb increases as the cement content increases, which is consistent with the change trend of WCS cohesion. With the increase of cement content from $5 \%$ to $7.5 \%$ and $10 \%$ in WCS, the cohesion increased by $107.5 \%$ and $182.8 \%$. It is assumed that more cements provided more active substances (such as $\mathrm{CaO}$ ), and more hydration products are generated correspondingly. The hydration products with high specific surface area improves the soil compactness. With the improvement of soil compactness, the grip force of soil particle on fibres is improved, thus the a)

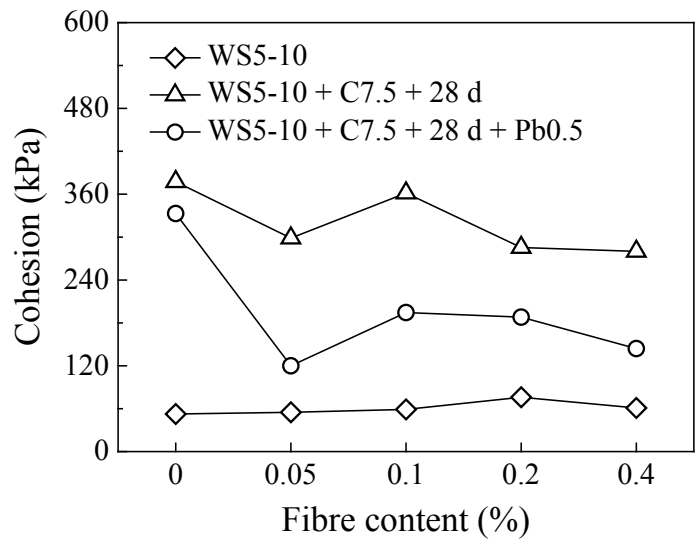

c)

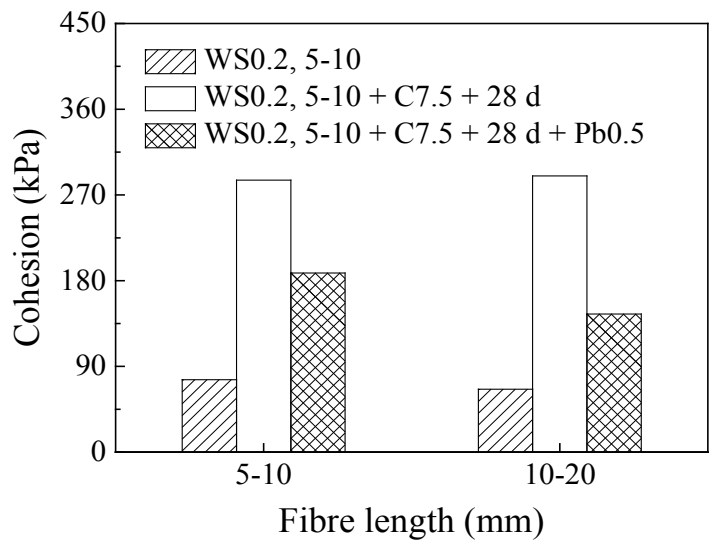

b)

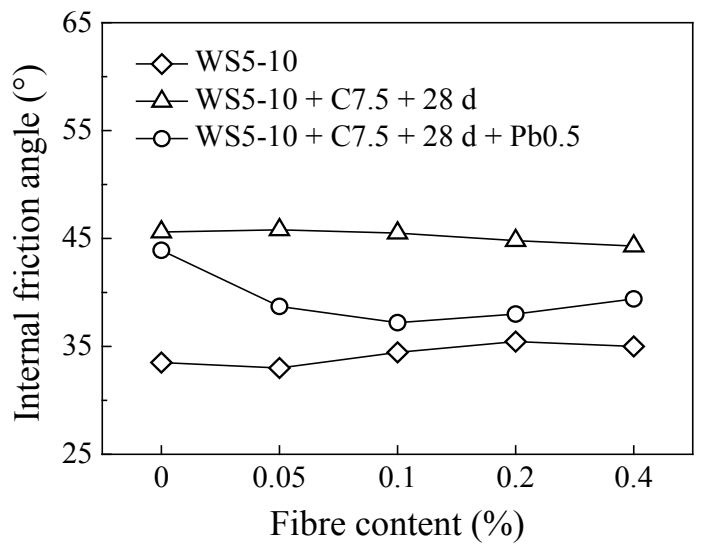

d)

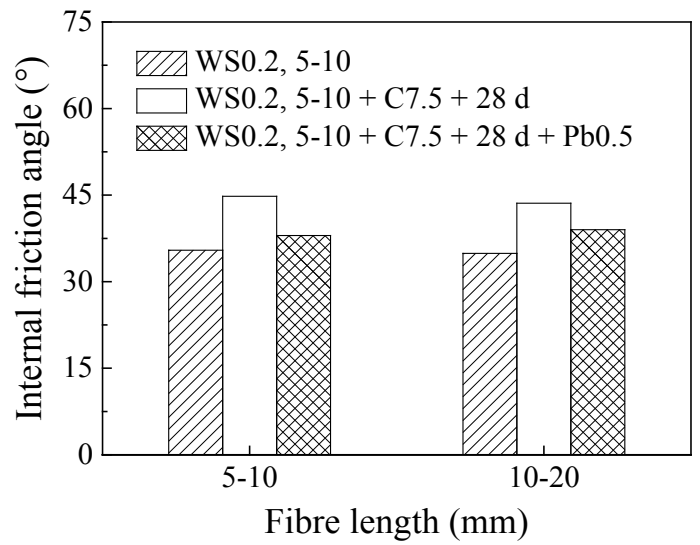

Fig. 4. Effects of fibre content and fibre length in direct shear test. 
strength of the soil is improved. The presence of $\mathrm{Pb}^{2+}$ exhibits a negative effect on the hydration reaction of cement, as a result, the cohesion of WCCS-Pb is less than that of WCS when in the same cement content. As the cement content increases, the cohesion difference between WCS and WCCS-Pb increases. To be specific, the cohesion difference between WCS and WCCS-Pb are $67.2 \mathrm{kPa}(5 \%$ cement $), 97.5 \mathrm{kPa}(7.5 \%$ cement $)$ and $160.2 \mathrm{kPa}(10 \%$ cement), respectively. In Fig. $5 \mathrm{~b})$, as the cement content increases, the internal friction angle of the soil increases as well, but the increase is slightly less than that of soil cohesion. It is indicated that cement content has a greater influence on the soil cohesion when compared with the internal friction angle [38-39].

Fig. 5c) shows the cohesion of WCS and WCCS$\mathrm{Pb}$ rises gradually with the increase of curing time. When the curing time rises from $7 \mathrm{~d}$ to $28 \mathrm{~d}$ and $90 \mathrm{~d}$, the cohesion of WCCS-Pb increases by $75.5 \mathrm{kPa}$ and $185.5 \mathrm{kPa}(36 \%$ and $88.3 \%$, respectively). When the curing time are $7 \mathrm{~d}, 28 \mathrm{~d}$ and $90 \mathrm{~d}$, the corresponding cohesion of WCCS-Pb decrease by $53.4 \mathrm{kPa}, 97.5 \mathrm{kPa}$ and $31 \mathrm{kPa}$ compared with that of WCS. The mechanism of shear strength via curing time is similar to that of cement content. As shown in Fig. 5(d), the internal friction angle of WCCS-Pb increases linearly. When the curing time increases from $7 \mathrm{~d}$ to $28 \mathrm{~d}$ and $90 \mathrm{~d}$, the internal friction angle of WCCS-Pb increases by $9.2^{\circ}$ and $15.3^{\circ}$. The variety of internal friction angle of WCS with curing time is not obvious and the internal friction angle difference between WCS and WCCS-Pb

a)

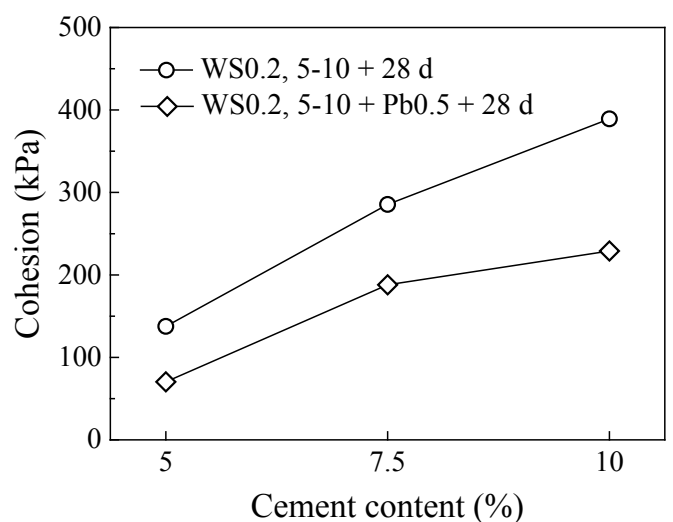

c)

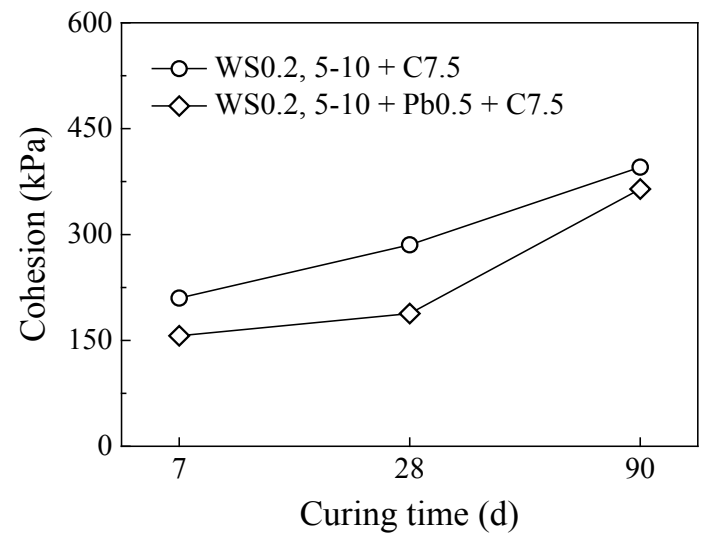

decrease. It is noted that hydration reaction of cement continues in the later of the curing period, and more hydrates are generated to adsorb and encapsulate $\mathrm{Pb}^{2+}$, which resulted in the reduction of $\mathrm{Pb}^{2+}$.

\section{Effects of Heavy Metal Content and Type}

The effect of heavy metal content on shear strength indexes is illustrated in Fig. 6a) and b). As the heavy metal content rises, the cohesion and internal friction angle of WCCS-Pb decreases gradually. When the cement content is $7.5 \%$ and the curing time is $28 \mathrm{~d}$, the cohesion of WCCS-Pb with $0.1 \%, 0.5 \%$ and $1 \% \mathrm{~Pb}^{2+}$ concentration is $204.6 \mathrm{kPa}, 188 \mathrm{kPa}$ and $114.7 \mathrm{kPa}$. The increase of $\mathrm{Pb}^{2+}$ concentration from $0.1 \%$ to $0.5 \%$ and $1 \%$ result in a decrease of the cohesion by $8.1 \%$ and $43.9 \%$, respectively. According to some studies, too much $\mathrm{Pb}^{2+}$ would hinder and delay the hydration of cement, and reduce the strength of soil as a result [29]. Fig. 6b) shows the decrease of internal friction angle of WCCS-Pb with the increase of $\mathrm{Pb}^{2+}$ concentration. To be detailed, some cracks may be formed in the curing of WCCS-Pb. With the amount of $\mathrm{Pb}^{2+}$ increases, the process of crack generation and expansion accelerates meanwhile.

Fig. 6c) and d) shows different heavy metal ions has different effects on shear strength indexes. When the heavy metal content is $0.5 \%$, the cohesive of WCCS-Pb reached the largest, followed by WCCS-Zn and WCCS$\mathrm{Cu}$. The solubility of lead chloride used in the test

b)

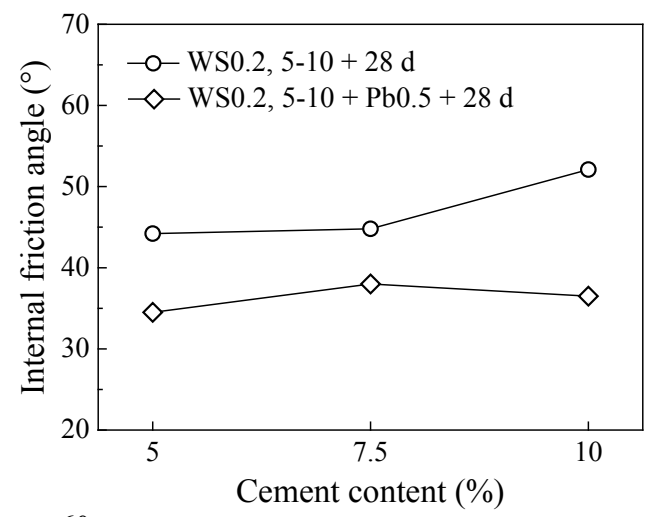

d)

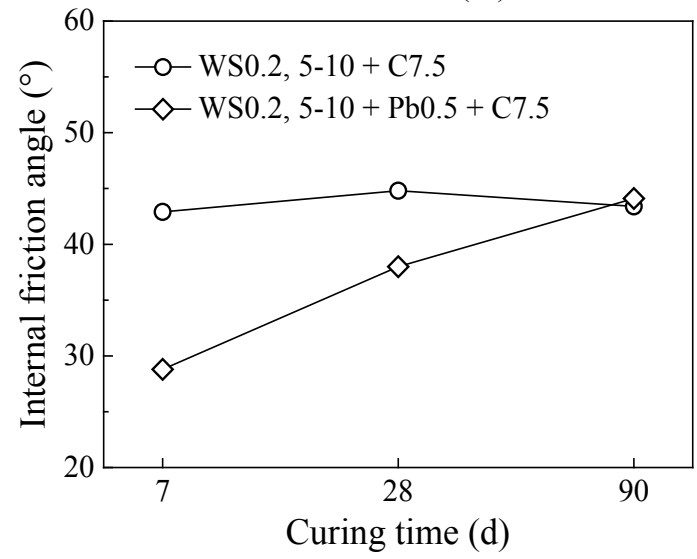

Fig. 5. Effects of cement content and curing time in direct shear test. 
a)

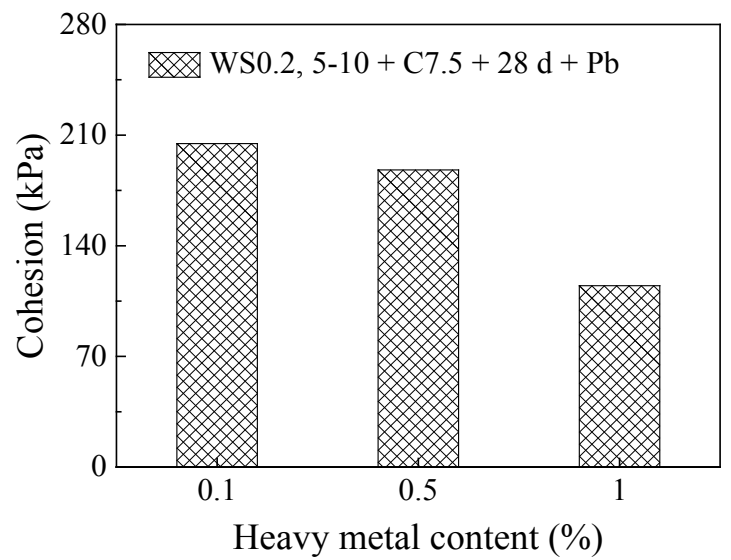

c)

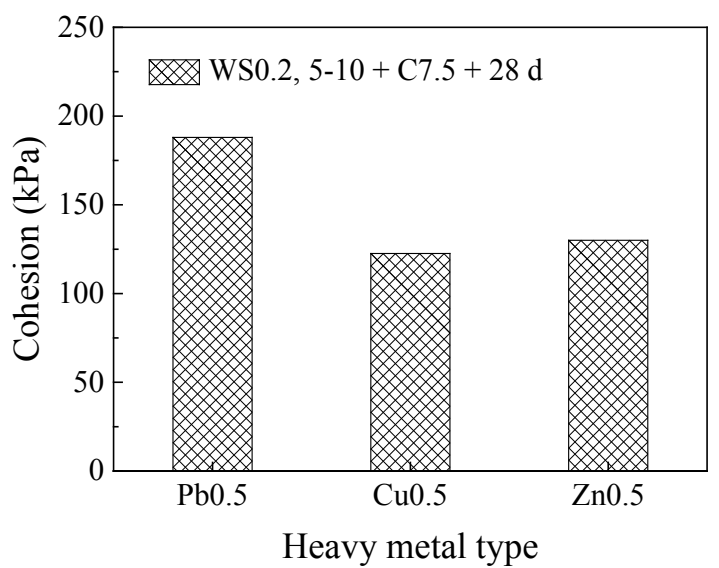

Fig. 6. Effects of heavy metal content and type in direct shear test.

is lower than that of copper chloride and zinc chloride. The internal friction angle of WCCS-Cu is the lowest. It can be found that $\mathrm{Zn}^{2+}$ had a greater impact on shear strength compared with the effect of $\mathrm{Cu}^{2+}$. According to some previous studies, when the concentration of $\mathrm{Zn}^{2+}$ is relatively high $(5000 \mathrm{mg} / \mathrm{kg})$, the $\mathrm{Zn}^{2+}$ solidification is mainly caused by the reaction of cement hydration products (such as calcium silicate hydrate) and $\mathrm{Zn}^{2+}$. As the result, the precipitates are formed, adsorbed on the surface of soil particles and fibres or existing in the pore of the soil. Besides, a large number of insoluble substances (such as $\mathrm{Ca}\left[\mathrm{Zn}(\mathrm{OH})_{3} \mathrm{H}_{2} \mathrm{O}\right]_{2}$ ) are formed by $\mathrm{Zn}^{2+}$ and precipitated when the test environment was alkaline. Therefore, the solidification effect of $\mathrm{Zn}^{2+}$ by cement is relatively better [40].

\section{Conclusions}

In this paper, the UCST and DST are conducted to investigate the UCS, failure strain, deformation modulus, cohesion and internal friction angle of WS, WCS and WCCS, by evaluating the influence of fibre content and length, cement content, curing time, heavy metal content and type. The results of WS and WCS are mainly used for contrast, while the mechanisms are b)

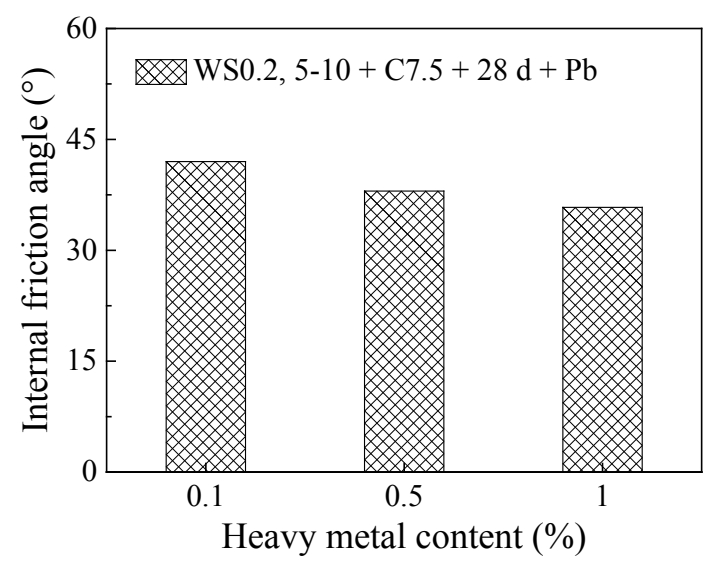

d)

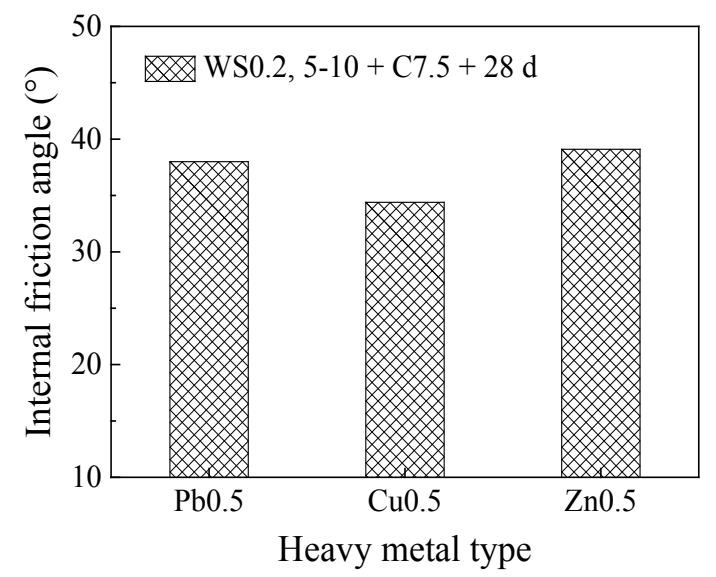

discussed and analysed. The following conclusions are reached:

1. The presence of heavy metal hinders the hydration of cement, thus the UCS, deformation modulus, cohesion and internal friction angle decrease.

2. The cement content and curing time have an active impact on WCS and WCCS-Pb. As cement content and curing time increase, the UCS, failure strain, deformation modulus, cohesion and internal friction angle increase, which is mainly caused by the effect of cement-hydrate.

3. With wheat straw added in the soil, the UCS, deformation modulus, cohesion and internal friction angle are not improved, while the failure strain increases gradually as fibre content increases. Therefore, wheat straw fibres can improve the soil deformation to some extent. Moreover, when fibre content is $0.2 \%$ and $0.1 \%$, the UCS of WCS and WCCS-Pb reaches maximum respectively.

4. It is noted that the singly use of wheat straw fibre or cement may not achieve the appropriate strength indexes, while a combined use of fibre and cement witnesses the better performance. The results confirm the validity of mechanical properties within fibre and cement reinforced heavy metal-contaminated soil. 


\section{Acknowledgments}

The research presented here is supported by the National Natural Science Foundation of China (52078317), Natural Science Foundation of Jiangsu Province for Excellent Young Scholars (BK20211597), project from Bureau of Housing and Urban-Rural Development of Suzhou (2021-25; 2021ZD02; 2021ZD30), Bureau of Geology and Mineral Exploration of Jiangsu (2021KY06), China Tiesiju Civil Engineering Group (2021-19), CCCC First Highway Engineering Group Company Limited (KJYF2021-B-19) and CCCC Tunnel Engineering Company Limited (8gs-2021-04).

\section{Conflict of Interest}

The authors declare that they have no conflicts of interest.

\section{References}

1. ZHANG J.H., PENG J.H., LIU W.Z., LU W.H., Predicting resilient modulus of fine-grained subgrade soils considering relative compaction and matric suction. Road Materials and Pavement Design, 22 (3), 703, 2019.

2. ZHANG J.H., GU F., ZHANG Y.Q., Use of buildingrelated construction and demolition wastes in highway embankment: Laboratory and field evaluations, Journal of Cleaner Production, 230, 1051, 2019.

3. ZHANG J.H., PENG J.H., ZHENG J.L., YAO Y.S., Characterisation of stress and moisture-dependent resilient behaviour for compacted clays in south China, Road Materials and Pavement Design, 21 (1), 262, 2018.

4. TANG Q., GU F., GAO Y.F., INUI T., KATSUMI T., Desorption characteristics of $\mathrm{Cr}(\mathrm{III}), \mathrm{Mn}(\mathrm{II})$ and $\mathrm{Ni}(\mathrm{II})$ in contaminated soil using citric acid and citric acid containing wastewater, Soils and Foundations, 58(1), 50, 2018.

5. ZHANG Y., TANG Q., CHEN S., GU F., LI Z.Z., Heavy metal adsorption of a novel membrane material derived from senescent leaves: kinetics, equilibrium and thermodynamic studies, Membrane Water Treat, 9 (2), 95, 2018.

6. TANG Q., ZHOU T., GU F., WANG Y., CHU J.M., Removal of $\mathrm{Cd}(\mathrm{II})$ and $\mathrm{Pb}(\mathrm{II})$ from soil through desorption using citric acid: kinetic and equilibrium studies, Journal of Central South University, 24 (9), 1941, 2017.

7. TANG Q., LIU W., LI Z., WANG Y., TANG X., Removal of aqueous $\mathrm{Cu}(\mathrm{II})$ with natural kaolin: kinetics and equilibrium studies, Environmental Engineering and Mantimement Journal, 17 (2), 467, 2018.

8. TANG Q., ZHANG Y., GAO Y., GU F., Use of cementchelated, solidified, municipal solid waste incinerator (MSWI) fly ash for pavement material: mechanical and environmental evaluations, Canadian Geotechnical Journal, 54 (11), 1553, 2017.

9. ZHA F.S., LIU J.J., CUI K.R., XU L., Utilization of cement for solidification/stabilization (s/s) of heavy metal contaminated soils, Disaster Advances, 5 (4), 1574, 2012.
10. ZHANG Y., TANG Q., SHI P., KATSUMI T., Influence of bio-clogging on permeability characteristics of soil. Geotextiles and Geomembranes, 49 (3), 707, 2021.

11. YIN C.Y., MAHMUD H.B., SHAABAN M.G., Stabilization/solidification of lead-contaminated soil using cement and rice husk ash, Journal of Hazardous Materials, 137 (3), 1758, 2006.

12. TANG Q., SHI P.X., YUAN Z., SHI S.J., XU X.J., KATSUMI T., Potential of zero-valent iron in remediation of $\mathrm{Cd}(\mathrm{II})$ contaminated soil: from laboratory experiment, mechanism study to field application, Soils and Foundations, 59 (6), 2099, 2019.

13. CHEN L., LIU S.Y., DU Y.J., JIN F., Unconfined compressive strength properties of cement solidified/ stabilized lead-contaminated soils, Chinese Journal of Geotechnical Engineering, 32 (12), 1898, 2010.

14. CHEN L., DU Y.J., LIU S.Y., JIN F., Experimental study of stress-strain properties of cement treatment leadcontaminated soils, Rock and Soil Mechanics, 32 (3), 715, 2011.

15. ZHANG J.H., PENG J.H., ZENG L., LI J., LI F., Rapid Estimation of Resilient Modulus of Subgrade Soils Using Performance-Related Soil Properties, International Journal of Pavement Engineering, 22 (6), 732, 2019.

16. GU F., SAHIN H., LUO X., LUO R., LYTTON R.L., Estimation of resilient modulus of unbound aggregates using performance-related base course properties, Journal of Materials in Civil Engineering, 27 (6), 1, 2015.

17. GU F., MA W.Y., WEST R.C., TAYLOR A.J., ZHANG Y.Q., Structural performance and sustainability assessment of cold central-plant and in-place recycled asphalt pavements: A case study, Journal of Cleaner Production, 208, 1513, 2019.

18. CONSOLI N.C., CASAGRANDE M.D.T., PRIETTO P.D.M., THOM A.É, Plate Load Test on Fibre-Reinforced Soil, Journal of Geotechnical and Geoenvironmental Engineering, 129 (10), 951, 2003.

19. HU X.Q., HONG L., XU G.L., YANG X., JIANG G.W., Impacts of Fibre Content and Fibre Length on the Strength and Deformation of Fibre Reinforced Soil, Safety and Environmental Engineering, 22 (2), 139, 2015.

20. TANG C.S., SHI B., GAO W., CHEN F.J., CAI Y., Strength and mechanical behavior of short polypropylene fibre reinforced and cement stabilized clayey soil, Geotextiles and Geomembranes, 25 (3), 194, 2007.

21. WEI L., CHAI S.X., CAI H.Z., LI M., Triaxial shear strength and deviatoric stress-strain of saline soils reinforced with wheat straws," China Civil Engineering Journal, 45 (1), 109, 2012.

22. ZHU S.D., WU Y.X., YU Z.N. CHEN Q.M., WU G.Y., YU F.Q., WANG C.W., JIN S.W., Microwave-assisted Alkali Pre-treatment of Wheat Straw and its Enzymatic Hydrolysis, Biosystems Engineering, 94 (3), 437, 2006.

23. FANG J.M., FOWLER P., TOMKINSON J., HILL C.A.S. Preparation and characterisation of methylated hemicelluloses from wheat straw," Carbohydrate Polymers, 47 (3), 285, 2002.

24. PANTHAPULAKKAL S., SAIN M., Injection Molded Wheat Straw and Corn Stem Filled Polypropylene Composites, Journal of Polymers and the Environment, 14 (3), 265, 2006.

25. JIANG D., ZHUANG D.F., FU J.Y., HUANG Y.H., WEN K., Bioenergy potential from crop residues in China: Availability and distribution, Renewable and Sustainable Energy Reviews, 16 (3), 1377, 2012. 
26. RADZI B.A.M., OROS D.R., SIMONEIT B.R. Biomass burning as the main source of organic aerosol particulate matter in Malaysia during haze episodes, Chemosphere, 55 (8), 1089, 2004.

27. HONG L., LIU G., ZHOU L., LI J., XU H., DAN W., Emission of organic carbon, elemental carbon and watersoluble ions from crop straw burning under flaming and smoldering conditions, Particuology, 31 (2), 181, 2017.

28. SHI C., SPENCE R., Designing of cement-based formula for solidification/stabilization of hazardous, radioactive, and mixed wastes, Critical Review in Environmental Science and Technology, 34 (4), 391, 2004.

29. ZHA F.S., HAO A.L., XU L., LIU J.J., CUI K.R., Experimental study of leaching characteristics of cement solidified and stabilized heavy metal contaminated soils, Industrial Construction, 44 (1), 65, 2014.

30. WU K., SHI H.S., XU L.L., GUO X.L., SCHUTTER G.D., XU M.F., Influence of heavy metals on the early hydration of calcium sulfoaluminate, Journal of Thermal Analysis and Calorimetry, 115 (2), 1153, 2014.

31. LUO X., BIRGISSON B., LYTTON R.L., Kinetics of healing of asphalt mixtures. Journal of Cleaner Production, 252, 1, 2020.

32. LI L.L., GAO Y.M., ZHANG Y.Q., Crack Length Based Healing Characterisation of Bitumen at Different Levels of Cracking Damage. Journal of Cleaner Production, 258 (1), $1,2020$.

33. YANG Q., LI X., ZHANG L., QIAN Y., QI Y., Kouhestani H., Shi X., Gui X., Wang, D., Zhong, J. Performance evaluation of bitumen with a homogeneous dispersion of carbon nanotubes. Carbon, 158, 465, 2020.

34. CHEN R.P., XU Z.Z., CHEN Y.M., Research on Key Problems of Pile-supported Reinforced Embankment. China Journal of Highway and Transport, 20 (2), 7, 2007.

35. TANG Q., KIM H.J., ENDO K., KATSUMI T., INUI T., Size effect on lysimeter test evaluating the properties of construction and demolition waste leachate, Soils and Foundations, 55 (4), 720, 2015.

36. HUANG Y.C., CHEN J., TIAN A.R., WU H.L., ZHANG Y.Q., TANG Q. Mechanical properties of fiber and cement reinforced heavy metal contaminated soils as roadbed filling. Journal of Central South University, 27 (7), 2003, 2020.

37. HUANG Y., GUAN Y., WANG L., ZHOU J., GE Z., HOU $Y$. Characterization of mortar fracture based on three point bending test and XFEM. International Journal of Pavement Research and Technology. 11 (4), 339, 2017.

38. HUANG Y., WANG L., XIONG H. Evaluation of pavement response and performance under different scales of APT facilities. Road Materials and Pavement Design. 18 (S3), 159, 2017.

39. TANG Q., KATSUMI T., INUI T., LI Z.Z., Membrane behavior of bentonite amended compacted clay, Soils and Foundations, 54 (3), 329-344, 2014.

40. TANG Q., GU F., ZHANG Y., ZHANG Y.Q., MO J.L., Impact of biological clogging on the barrier performance of landfill liners, Journal of Environmental Management, 222, 44, 2018. 